\title{
Studies on dehydration of figs using different sugar syrup treatments
}

\author{
Naikwadi P. M. - Chavan U. D. - Pawar V. D. - Amarowicz R.
}

Revised: 8 February 2010 / Accepted: 11 February 2010

(C) Association of Food Scientists and Technologists (India), Mysore

\begin{abstract}
The ripe fig (Ficus carica L) fruits of cultivar cv., 'Deanna' were steam treated at $90^{\circ} \mathrm{C}$ and 10 psi for $5 \mathrm{~min}$ in autoclave. Steamed fruits were dipped in sucrose, glucose, fructose and invert sugar syrups at $50^{\circ}$ Brix for 24 $\mathrm{h}$ for getting desired total soluble solids content. The treated fruits were further dried to $20 \%$ moisture in a cabinet dryer at $50-55^{\circ} \mathrm{C}$. Good quality and acceptable dried figs could be prepared by using invert sugar syrup treatment. Dried figs prepared using invert sugar and packed in aluminum foil pouch and stored at ambient $\left(27 \pm 2^{\circ} \mathrm{C}\right)$ as well as refrigerated $\left(10 \pm 2^{\circ} \mathrm{C}\right)$ temperature remained in excellent condition up to 6 months.
\end{abstract}

Keywords Dehydrated fig · Sugar syrup · Fructose . Invert sugar
Naikwadi P. M. · Chavan U. D. · Pawar V. D. ·

Amarowicz R.

${ }^{1}$ Department of Food Science and Technology,

Mahatma Phule Krishi Vidyapeeth,

Rahuri - 413 722, India

${ }^{2}$ Institute of Animal Reproduction and Food Research of the

Polish Academy of Sciences,

Division of Food Science, Olsztyn, Poland

Chavan U. D. $(\bowtie)$

E-mail: uttamchavan08@gmail.com

\section{Introduction}

Fig (Ficus carica L) is under cultivation since ancient times and its remnants found in excavations of sites traced to at least $5000 \mathrm{BC}$ (Anon 2002a). Fig is now cultivated chiefly and commercially in USA, Chile, Afghanistan, Italy, Greece, Algeria and India. In India, its cultivation is mostly confined to Western part of Maharashtra (Pune and Aurangabad), Gujarat, Uttar Pradesh (Lukhnow and Saharanpur), Karnataka (Bellary, Chitradurga and Shrirangpatham), Punjab (Anantpur) and Tamilnadu (Coimbatore). The total area in India under fig cultivation is about 1500 ha of which about 883 ha in Maharashtra with the production of 2650 metric tonnes (Anon 2002b). In recent years, India exported about 633 Metric tonnes figs of value Rs. 49.04 lakhs to many countries (Singhal 2003).

Fig is delicious, nutritive fruit and has medicinal properties such as reducing risk of cancer and heart disease (Vinson 1999). Fig fruit is consumed fresh, dried, preserved, canned and candied. In Mediterranean region, it is used for alcohol and wine production while in Europe for figcoffee preparation. The period of availability of fig fruits commences in March, continues up to June, the peak period being April and May. Being highly perishable, fig cannot be stored for longer period at ambient condition. The dried figs can be stored for 6-8 months (Venkataratnam 1988). To get good quality dehydrated product, osmotic dehydration in combination with other drying methods is useful. Osmotic dehydration consists of partial removal of moisture from the produce by placing it in concentrated sugar solution. The product prepared by this method showed a porous crispy structure and retained a large percentage of flavour volatiles of fresh fruits (Pointing et al. 1966). Considering these points, there is greater scope and need for drying of figs for making it available throughout the year in good quality. Also there is a necessity of developing an appropriate technology for drying of figs with longer shelf life. Prepared dried figs become very hard and turn into 
white colour due to sugar crystallization on the surface of dried figs. Therefore, different sugar syrups were tried for preparing dehydrated figs to find out their effect on sensory quality and changes that take place in chemical composition during storage.

\section{Materials and methods}

Sugars were obtained from Vijay Trading Corporation, Shrirampur, India. The fig fruits cv., 'Deanna' of uniform and medium size was obtained from All India Co-ordinated Research Project on Arid Zone fruits, Department of Horticulture, Mahatma Phule Krishi Vidyapeeth, Rahuri, India. The clean fruits were subjected to steam treatment at $90^{\circ} \mathrm{C}$ and 10 psi for $5 \mathrm{~min}$ in autoclave. Steamed fruits were dipped in $50^{\circ}$ Brix syrup of sucrose, glucose, fructose and invert sugar (glucose 50\% + fructose 50\%) syrup for $24 \mathrm{~h}$ to get desired total soluble solids (TSS). The soaked fruits were removed from syrup and surface of fruits were subjected to drying in the cabinet dryer at $50-55^{\circ} \mathrm{C}$ for $18-20 \mathrm{~h}$ to reduce moisture content to safe level of $18-20 \%$ (Thonta and Patil 1988). The yield percentage of dried figs was calculated on the basis of fresh fruit weight. The dried fruits were packed in aluminum foil pouch and stored at ambient $\left(25 \pm 2{ }^{\circ} \mathrm{C}\right)$ and refrigerated $\left(10 \pm 2^{\circ} \mathrm{C}\right)$ temperatures. Market samples of dehydrated figs were procured from the local market for sensory and chemical analysis for comparison.

Chemical analysis and sensory characteristics were studied at 0 and 6 months storage. Moisture, TSS and titratable acidity were estimated using AOAC (1990) method. Reducing, non-reducing and total sugars were determined using Lane and Eynon method (1923) while ascorbic acid content was estimated by employing direct titration of filtrate with 2-6 dichlorophenol indophenols dye according to AOVC (1966).

Sensory evaluation was performed by a panel of 10 semi-trained judges on the basis of 9-point Hedonic scale (Amerine et al. 1965). The microbial spoilage (standard plate count) was studied as per the method of Harrigan and Mccance (1966) and Speck (1976). Statistical analysis was done as per the procedure described by Panse and Sukhatme (1967) using minimum three replications.

\section{Results and discussion}

Sensory quality of fresh dried figs: Sensory quality parameters of fresh dehydrated figs showed excellent organoleptic characteristics for fructose sugar syrup and invert sugar syrup treatments for colour and appearance, texture, taste and overall acceptability as compared to other treatments as well as to market samples (Table 1). The fresh dried figs contained about $19 \%$ moisture, $55^{\circ}$ Brix (TSS), $42 \%$ reducing sugars, $0.08 \%$ acidity and $2.3 \mathrm{mg} \%$ vitamin $\mathrm{C}$ in syrup treated samples. Chemical or nutritional composition of fresh dehydrated figs prepared by fructose and invert sugar syrup treatment showed higher TSS, reducing sugars and total sugars than the control and market samples but comparable to other treatments. Thonta and Patil (1988) reported that maximum TSS was in fruits treated with pretreatments of dry sugar followed by pricked as well as non pricked fruits dipped in sugar solution and subjected to oven drying $\left(58 \pm 3^{\circ} \mathrm{C}\right)$ for 2 days. Gawade and Waskar (2003) found that blanching plus sulphitation was the best pre-treatment for preparation of dried figs. Thonta and Patil (1988) and Pawar et al. (1992) also reported similar results

Table 1 Sensory quality and chemical composition of fresh dehydrated figs

\begin{tabular}{|c|c|c|c|c|c|c|c|}
\hline & \multicolumn{7}{|c|}{ Treatments } \\
\hline & Control & Sucrose & Glucose & ictose & Invert sugar & Market sample & C.D. at $5 \%(n=3)$ \\
\hline \multicolumn{8}{|c|}{ Sensory quality } \\
\hline Colour and appearance & 6.0 & 7.5 & 7.3 & 8.0 & 7.8 & 6.0 & 2.44 \\
\hline Flavour & 7.0 & 7.5 & 7.3 & 8.5 & 8.3 & 7.0 & 1.76 \\
\hline Texture & 6.6 & 7.3 & 7.0 & 8.4 & 8.1 & 6.3 & 2.23 \\
\hline Taste & 6.6 & 7.8 & 7.0 & 8.4 & 8.9 & 7.3 & 2.34 \\
\hline Overall acceptability & 6.6 & 7.5 & 7.1 & 8.3 & 8.3 & 6.7 & 2.06 \\
\hline Rank & 6 & 3 & 4 & 1 & 2 & 5 & - \\
\hline \multicolumn{8}{|c|}{ Chemical composition } \\
\hline Moisture, $\%$ & 19.1 & 18.8 & 19.0 & 18.1 & 19.1 & 18.3 & 1.09 \\
\hline $\mathrm{TSS},{ }^{0}$ Brix & 31.2 & 55.7 & 55.8 & 55.6 & 55.5 & 38.2 & 29.31 \\
\hline Reducing sugars, $\%$ & 21.1 & 36.7 & 42.0 & 42.3 & 41.9 & 31.4 & 25.01 \\
\hline Non-reducing sugars, $\%$ & 2.0 & 8.6 & 3.9 & 3.7 & 3.8 & 2.1 & 2.14 \\
\hline Total sugars, $\%$ & 24.1 & 45.3 & 45.9 & 46.0 & 46.7 & 33.2 & 26.26 \\
\hline Ascorbic acid, mg/100 g & 2.4 & 2.2 & 2.3 & 2.3 & 2.3 & 1.8 & 0.19 \\
\hline Titratable acidity, \% & 0.089 & 0.076 & 0.076 & 0.071 & 0.069 & 0.160 & 0.021 \\
\hline
\end{tabular}


for total sugars content in dried figs. Bolin and King (1980) showed that ascorbic acid in dried figs ranged from 2.6 to $3.6 \mathrm{mg} / 100 \mathrm{~g}$.

Storage study: There was a gradual decrease in score after 6 months storage for colour and appearance, flavour, texture, taste and overall acceptance in all samples at ambient as well as at refrigerated storage temperature (Table 2). Fresh dried figs prepared using fructose and invert sugar syrup gave first and second rank with highest overall acceptability score. Similar trend was observed after 6 months in fruits stored at ambient and refrigerator conditions. Refrigerated storage obtained higher score for all sensory properties than those stored at ambient condition. Gawade and Waskar (2003) found that dried figs prepared from 'Poona' and 'Dinkar' varieties could be stored for more than 180 days at low temperature, which maintained physico-chemical characteristics and rated highest organolpetic score for better market acceptability. Similar observations were reported for dried figs with respect to storage temperature and period by Deol and Bhullar (1972), Gouda et al. (1975) and Thonta and Patil (1988).

There was gradual decrease in moisture, acidity and ascorbic acid but increase in sugars content during stor- age (Table 3). The rate of decrease or increase was faster at ambient than at cool storage conditions. This might be due to the change in temperature during storage conditions and oxidation of ascorbic acid at steaming as well as at high temperature storage (Thonta and Patil 1988, Pawar et al. 1992, Waskar et al. 2003). Ascorbic acid content of dried figs stored at refrigerated temperature was higher (1.3 to $2.0 \mathrm{mg} / 100 \mathrm{~g}$ ) than that of stored at ambient temperature $(1.0$ to $1.6 \mathrm{mg} / 100 \mathrm{~g}$ ). The cost of production of $1 \mathrm{~kg}$ dried figs using sucrose, glucose, fructose and invert sugar syrups at pilot plant is approximately Rs 226, 236, 287 and 259, respectively. The market cost of dried figs varies from Rs 350 to Rs $400 / \mathrm{kg}$. This study revealed that the dehydrated figs prepared by using fructose or invert sugar syrup $(50 \%$ glucose $+50 \%$ fructose) maintained their market acceptability for 6 months. It is apparent from above observations that fructose sugar syrup or invert sugar syrup is best suited for preparation of dried figs. Since fructose is costly, invert sugar can be used for production of best quality figs.

Microbial quality: Treatment with invert sugar syrup and 6 months storage at refrigerated condition showed less microbial count (3.7 log cfu/g) than at ambient condition (3.9 $\log \mathrm{cfu} / \mathrm{g}$ ) and market samples.

Table 2 Sensory quality score of dehydrated figs (after 6 months storage)

\begin{tabular}{|c|c|c|c|c|c|c|c|c|c|c|c|c|}
\hline \multirow[t]{2}{*}{ Treatment } & \multicolumn{2}{|c|}{$\begin{array}{l}\text { Colour and } \\
\text { appearance }\end{array}$} & \multicolumn{2}{|c|}{ Flavour } & \multicolumn{2}{|c|}{ Texture } & \multicolumn{2}{|c|}{ Taste } & \multicolumn{2}{|c|}{$\begin{array}{c}\text { Overall } \\
\text { acceptability }\end{array}$} & \multicolumn{2}{|c|}{ Ranks } \\
\hline & A & $\mathrm{R}$ & A & $\mathrm{R}$ & A & $\mathrm{R}$ & A & $\mathrm{R}$ & A & $\mathrm{R}$ & A & $\mathrm{R}$ \\
\hline Control & 4.0 & 4.5 & 6.0 & 6.0 & 5.0 & 5.7 & 5.6 & 6.0 & 5.2 & 5.5 & 5 & 6 \\
\hline Sucrose & 5.0 & 6.5 & 6.0 & 6.3 & 5.5 & 5.0 & 6.0 & 6.7 & 5.6 & 6.1 & 4 & 3 \\
\hline Glucose & 5.0 & 5.0 & 5.7 & 6.0 & 4.5 & 5.0 & 5.3 & 5.3 & 5.1 & 6.0 & 6 & 4 \\
\hline Fructose & 7.3 & 7.3 & 7.7 & 8.0 & 8.0 & 8.0 & 7.7 & 8.0 & 7.8 & 7.8 & 1 & 1 \\
\hline Invert sugar & 7.0 & 7.3 & 7.3 & 8.0 & 8.0 & 7.5 & 7.5 & 8.0 & 7.5 & 7.7 & 2 & 2 \\
\hline Market sample & 3.5 & 4.5 & 6.5 & 6.0 & 6.0 & 6.0 & 7.0 & 7.0 & 5.8 & 5.9 & 3 & 5 \\
\hline C.D. at $5 \%(n=3)$ & 4.3 & 3.7 & 2.2 & 2.7 & 4.1 & 3.5 & 2.7 & 2.9 & 3.2 & 2.7 & - & - \\
\hline
\end{tabular}

$\mathrm{A}=$ Ambient $\left(25 \pm 2^{\circ} \mathrm{C}\right), \mathrm{R}=$ Refrigerated $\left(10 \pm 2^{\circ} \mathrm{C}\right)$

Table 3 Effect of storage period and syrup treatments on chemical composition of dehydrated figs after 6 months storage

\begin{tabular}{|c|c|c|c|c|c|c|c|c|c|c|c|c|c|c|c|c|}
\hline \multirow[t]{2}{*}{ Treatment } & \multicolumn{2}{|c|}{$\begin{array}{l}\text { Moisture, } \\
\%\end{array}$} & \multicolumn{2}{|c|}{$\mathrm{TSS},{ }^{0}$ Brix } & \multicolumn{2}{|c|}{$\begin{array}{l}\text { Reducing } \\
\text { sugars, \% }\end{array}$} & \multicolumn{2}{|c|}{$\begin{array}{c}\text { Non- } \\
\text { Reducing } \\
\text { sugars, \% }\end{array}$} & \multicolumn{2}{|c|}{$\begin{array}{c}\text { Total sugars, } \\
\%\end{array}$} & \multicolumn{2}{|c|}{$\begin{array}{c}\text { Ascorbic } \\
\text { acid, mg/ } \\
100 \mathrm{~g}\end{array}$} & \multicolumn{2}{|c|}{$\begin{array}{l}\text { Titratable } \\
\text { acidity, \% }\end{array}$} & \multicolumn{2}{|c|}{$\begin{array}{c}\text { Standard } \\
\text { plate count } \\
\log \mathrm{cfu} / \mathrm{g}\end{array}$} \\
\hline & A & $\mathrm{R}$ & A & $\mathrm{R}$ & A & $\mathrm{R}$ & $\mathrm{A}$ & $\mathrm{R}$ & A & $\mathrm{R}$ & $\mathrm{A}$ & $\mathrm{R}$ & $\mathrm{A}$ & $\mathrm{R}$ & $\mathrm{A}$ & $\mathrm{R}$ \\
\hline Control & 17.5 & 18.2 & 35.0 & 31.0 & 24.1 & 20.9 & 2.2 & 2.6 & 26.3 & 23.5 & 1.0 & 1.3 & 0.09 & 0.07 & 3.9 & 3.7 \\
\hline Sucrose & 16.3 & 17.5 & 57.1 & 56.7 & 40.7 & 38.4 & 7.3 & 7.5 & 48.0 & 45.9 & 1.5 & 1.9 & 0.07 & 0.06 & 3.9 & 3.7 \\
\hline Glucose & 16.8 & 18.2 & 56.9 & 56.3 & 44.4 & 43.7 & 3.1 & 3.2 & 47.6 & 46.9 & 1.5 & 1.9 & 0.07 & 0.06 & 3.9 & 3.7 \\
\hline Fructose & 16.4 & 17.6 & 57.1 & 56.8 & 45.8 & 44.1 & 3.0 & 3.1 & 48.7 & 47.1 & 1.5 & 1.8 & 0.07 & 0.05 & 3.9 & 3.7 \\
\hline Invert sugar & 17.4 & 17.8 & 57.1 & 56.9 & 43.9 & 43.6 & 3.5 & 3.4 & 47.4 & 47.2 & 1.6 & 1.9 & 0.06 & 0.06 & 3.8 & 3.7 \\
\hline Market sample & 17.9 & 18.5 & 38.4 & 38.6 & 31.5 & 31.8 & 2.2 & 2.2 & 33.2 & 33.7 & 1.6 & 1.6 & 0.18 & 0.15 & 4.9 & 4.9 \\
\hline $\begin{array}{l}\text { C.D. at } 5 \% \\
(n=3)\end{array}$ & 1.5 & 0.9 & 26.4 & 30.8 & 24.8 & 27.1 & 1.3 & 0.9 & 26.0 & 27.9 & 0.6 & 0.7 & 0.04 & 0.04 & 1.2 & 1.4 \\
\hline
\end{tabular}

$\mathrm{A}=$ Ambient $\left(25 \pm 2^{\circ} \mathrm{C}\right), \mathrm{R}=$ Refrigerated $\left(10 \pm 2^{\circ} \mathrm{C}\right)$ 


\section{Conclusion}

The clean fruits were subjected to steam treatment at $90^{\circ} \mathrm{C}$ and $10 \mathrm{psi}$ for $5 \mathrm{~min}$ in autoclave. Steamed fruits were dipped in $50^{\circ}$ Brix syrup of sucrose, glucose, fructose and invert sugar (glucose $50 \%+$ fructose $50 \%$ ) syrup for $24 \mathrm{~h}$ to get desired TSS. This study revealed that the dehydrated figs prepared by using fructose or invert sugar syrup (50\% glucose $+50 \%$ fructose) maintained their market acceptability for 6 months. Invert sugar syrup treatment is the best for preparation of dried figs of good quality.

\section{References}

Amerine MA, Pangborn RM, Roessler EB (1965) Principles of sensory evaluation of food. Academic Press, New York, p 350-480

Anon (2002a) Fig common. http://www/botanical.com/botanical/ $\mathrm{mgmh} /$ fig.com.12.Html (Accessed in January 2008)

Anon (2002b) Survey of fruit and vegetable. Directorate of Horticulture, Pune, $p$ 17-22

AOAC (1990) Official methods of analysis. $15^{\text {th }}$ edn, Association of Official Analytical Chemists, Washington DC

AOVC (1966) Methods of vitamin assay. $3^{\text {rd }}$ edn, Association of Vitamin Chemists, Interscience Publ, New York, p 287

Bolin HR, King AD (1980) Figs, tropical and subtropical fruits: composition, properties and uses. AVI, West Port, CT, p 492-505

Deol JS, Bhullar DS (1972) Effect of wrappers and growth regulators on the storage life of mango fruit. Punjab Hort J 12 (2-3): $114-119$

Gawade MH, Waskar DP (2003) Studies on processing and storage of fig fruits. J Maharashtra Agric Univ 28:148-150
Gouda MS, Zouil MB, El-Zalaki EM, Mohamed M (1975) Technological studies on fig varieties planted in Arab Republic of Egypt. Alexandria J Agric Res 25:459-466

Harrigan WF, Mccance ME (1966) Laboratory methods in microbiology. Academic Press, London, p 14-16

Lane JH, Eynon L (1923) Determination of sugars by fehling solution with methylene blue as an internal indicator. J Soc Chem India 42:32-34

Panse VP, Sukhatme PV (1967) Statistical methods for agricultural workers. Indian Council of Agricultural Research, New Delhi, p 70-72

Pawar SG, Kulkarni DN, Shere DM, Kulkarni KD, Patil VK (1992) Effect of pretreatment on chemical composition and drying rates of solar dried figs. Indian Food Packer 1: 39-44

Pointing JD, Wattress GG, Forrey RR, Jackson R, Stamley WL (1966) Osmotic dehydration of fruits. Food Technol 20(10): 125-131

Singhal V (2003) Indian agriculture-2003. Fruits and vegetables. Indian Economic Data Research Centre, New Delhi, p 215

Speck ML (1976) Compendium of methods for the microbiological examination of foods. American Public Health Association, Washington DC

Thonta GT, Patil VK (1988) Studies on drying of fig fruits. Indian Food Packer 42:94-99

Venkataratnam L (1988) Packaging of figs. A Souvenir on packaging of fruits and vegetables in India. Agriculture Horticultural Society Public Gardner, Hyderabad, p 112-114

Vinson JA (1999) The functional food properties of fig. Cereal Food World 44:82-87

Waskar DP, Gawade MH, Masalkar SD (2003) Processing and storage of fig fruit - a review J Maharashtra Agric Univ 28: $137-141$ 